\title{
Mechanisims of asthma and allergic disease - 1084. Localization and up-regulation of CysLT2 receptorin perennial allergic rhinitis
}

\author{
Hideaki Shirasaki ${ }^{*}$, Etsuko Kanaizumi ${ }^{2}$, Nobuhiko Seki ${ }^{2}$, Manabu Fujita ${ }^{3}$, Tetsuo Himi ${ }^{2}$ \\ From 2nd WAO International Scientific Conference (WISC 2012) \\ Hyderabad, India. 6-9 December 2012
}

\section{Background}

The cysteinyl leukotrienes (CysLTs) are lipid mediators that have been implicated in the pathogenesis of allergic rhinitis. Pharmacological studies using CysLTs indicate two classes of receptors named $\mathrm{CysLT}_{1}$ and $\mathrm{CysLT}_{2}$ receptor exist. The former is sensitive to the $\mathrm{CysLT}_{1}$ receptor antagonists currently used to treat asthma and allergic rhinitis. We have previously reported the localization of $\mathrm{CysLT}_{1}$ receptor by using immunohistochemistry and in situ hybridization. To clarify the expression of $\mathrm{CysLT}_{2}$ receptor in human nasal mucosa, we investigated the expression and the localization of CysLT 2 receptor in human nasal mucosa by means of Western blot analysis and immunohistochemistry.

\section{Methods}

Human turbinates were obtained by turbinectomy from 12 patients with nasal obstruction refractory to medical therapy. $\mathrm{CysLT}_{2}$ receptor expression on nasal mucosa was studied by Western blot analysis and immunohistochemistry. Also, to investigate the possible modulation of $\mathrm{CysLT}_{2}$ receptor expression, human umbilical vein endothelial cells (HUVECs) were stimulated with IL-4 or IL-13, and CysLT $\mathrm{T}_{2}$ receptor expression were evaluated by Western blot analysis.

\section{Results}

About $40 \mathrm{kDa}$ band was detected in human turbinates by western blot analysis using anti-CysLT $\mathrm{T}_{2}$ receptor antibody. The expression level of $\mathrm{CysLT}_{2}$ receptor protein was marked in patients with nasal allergy than in patients with non-allergic rhinitis. The immunohistochemical study

${ }^{1}$ Otolaryngology, Sapporo Medical University, Sapporo, Japan

Full list of author information is available at the end of the article revealed that both vascular endothelial cells and vascular smooth muscles showed intense immunoreactivity for CysLT $_{2}$ receptor. IL-13 enhanced the levels of CysLT2 receptor protein in HUVECs.

\section{Conclusions}

The results suggest a primary role for $\mathrm{CysLT}_{2}$ receptor as the vascular responses in upper respiratory tract,and vascular $\mathrm{CysLT}_{2}$ receptor expression can be regulated by Th2 cytokines.

\section{Author details}

'Otolaryngology, Sapporo Medical University, Sapporo, Japan. ${ }^{2}$ Sapporo Medical University, Japan. ${ }^{3}$ Minase Research Institute, Ono Pharmaceutical, Japan.

Published: 23 April 2013

doi:10.1186/1939-4551-6-S1-P80

Cite this article as: Shirasaki et al:: Mechanisims of asthma and allergic disease - 1084. Localization and up-regulation of CysLT2 receptorin perennial allergic rhinitis. World Allergy Organization Journal 2013 6(Suppl 1):P80.

Submit your next manuscript to BioMed Central and take full advantage of:

- Convenient online submission

- Thorough peer review

- No space constraints or color figure charges

- Immediate publication on acceptance

- Inclusion in PubMed, CAS, Scopus and Google Scholar

- Research which is freely available for redistribution

\section{Ciomed Central}

